821.163.41.09-1 Војичић, Милован

https://doi.org/10.18485/msc.2020.49.2.ch9

Саша Д. КНЕЖЕВИЋ ${ }^{*}$

Универзитет у Источном Сарајеву

Филозофски факултет
Оригинални научни рад

Примљен: 13. 11. 2019.

Прихваћен: 12. 02. 2020.

\title{
ВОЈВОДСТВО СВЕТОГА САВЕ У ПЈЕСМАМА МИЛОВАНА ВОЈИЧИЋА
}

\begin{abstract}
Свети Сава се у пјесмама најзначајнијег Перијевог сарадника Милована Војичића појављује веома често, али смо за овај рад одабрали десетак пјесама у којима је он главни јунак. У Војичићевом опусу ћемо покушати пронаћи утицаје ранијих пјесничких варијаната, али и легенди и других прозних врста веома распрострањених у његовом завичају. Милован Војичић Херцеговину доживљава као Војводство Светога Саве, а самога светитеља као божјег првоугодника, учитеља и чувара народног, и стога је занимљиво анализирати како он старије варијанте прилагођава сопственој визији.
\end{abstract}

Кључне ријечи: Свети Сава, војводство, Војичић, Пери, Херцеговина, варијанте.

Још од објављивања чувене збирке Светозара Ћоровића Педесет легенди о Светом Сави у науци је општеприхваћена теза о томе да је на простору Херцеговине, у најширем значењу њеног просторног одређења кроз историју, најдуже и најживље живјела усмена традиција о нашем најпознатијем и најпоштованијем светитељу. Обаштињењу Светога Саве на овим просторима највише је допринијела Српска православна црква, првенствено преко манастира Милешева, у који су свечеве мошти пренесене из Трнова. „Тај култ су после примили и владари из споредне немањићке линије, као босанскосрпски краљ Твртко I, који се баш у Милешеву, над гробом Светог Саве, дао крунисати за краља; и после Степан Вукчић, који се прогласио „херцегом од Светог Саве". У Милешеву је, несумњиво ради значаја Светог Саве, било једно време и седиште херцеговачког митрополита" (Һоровић 1995: 5).

У приповијеткама, по правилу, Свети Сава „додуше хришћански је светац, и врло ревносни пропагатор Христове вере; у суштини, међутим по своме карактеру и темпераменту, по митовима и веровањима који се за њега везују, припада он још старом, претхришћанском времену" (Чајкановић 1973: 149). Својеврсна амбивалентност око његовог имена по Ненаду

\footnotetext{
*sasa.knezevic@ffuis.edu.ba
} 
Љубинковићу (2010: 197-198), не само да није случајна него је посљедица његове свјесне радње: „Суштинска особеност повести о светом Сави јесте у чињеници да је он сам, свесно и смишљено, властити земаљски живот водио, кројио и прекрајао намерен да од себе у народним очима начини изузетну, култну личност. Народ је отвореног срца прихватио Савин самоизграђени култ. У особеној рецепцији тога култа, народ је Сави доделио улогу националног културног хероја, мудрог праучитеља и заштитника. Легенда о светом Сави није никада била противречна, а њен носилац је вазда био оличење свега позитивног".

С обзиром на то да је Свети Сава у усмено предање српског народа, па самим тим и у народну пјесму дошао посредно, преко писаних дјела црквене провинијенције и његов лик је преживио битну трансформацију, односно својеврсну духовну пререгистрацију кроз овако онеобичену цзензуру колектива, односно, према Александру Ломи (2013: 1070): „Историја духовности има своју специфичну динамику која се не одликује једносмерним токовима и оштрим резовима, већ се претежно састоји од непрестаног прожимања старог са новим, свога са страним. Из тога проистиче испреплетена и често замршена структура коју при ближем погледу разазнајемо у разним временским пресецима своје културне прошлости. На таквој позадини само се боље и јасније оцртава индивидуална величина Светог Саве и његовог духовног подвига".

Пишући управо о међуодносу епске пјесме и српске средњовјековне књижевности, Нада Милошевић Ђорђевић (1998: 323) с правом констатује: „Савин лик тако постаје својеврсна симбиоза врлине великих људи и историје и врлине светаца". Сразмјерно укупном броју, пјесама најстаријих времена и оних о Светом Сави је мало, поготово у односу на број легенди и народних предања. Заправо, Вук Караџић ће три пјесме о Светом Сави објавити међу пјесмама средюијех времена, у којима је он већ формирани епизовани лик. Отуда и не изненађује да у великом корпусу пјесама херцеговачког гуслара Милована Војичића у Милман Перијевој колекиији усмене књижевности, која се чува у Центру за Хеленистичке студије Харвардске библиотеке, тек њих пет пјевају о Светом Сави.

„Најзаступљенији певач у дигиталној Перијевој збирци је Милован Војичић из околине Невесиња, гуслар који се одликовао великом тематском разноврсношћу својих песама. Теме којима се бавио протежу се од преткосовских времена („ККако се Свети Сава закалуђерио”...), Косовског боја („Кнез Лазар и Милош Обилић”...), до најактуелнијих збивања („Смрт бечкога ћесара"...)” (Стевановић 2009: 63). Велика разноврсност пјесама поред којих Пери ставља Војичићево име је посљедица квантитета, али је могуће да је на њу утицао и сам сакупљач који је са Војичићем био у непрестаној преписци након њиховог сусрета у љето 1933. године, што потврђује и Војичићева порука Перију, прикачена уз пјесму Смрт краља Стевана Дечанског (135), посљедњу у свесци послатој 25. фебруара 1933. године: 


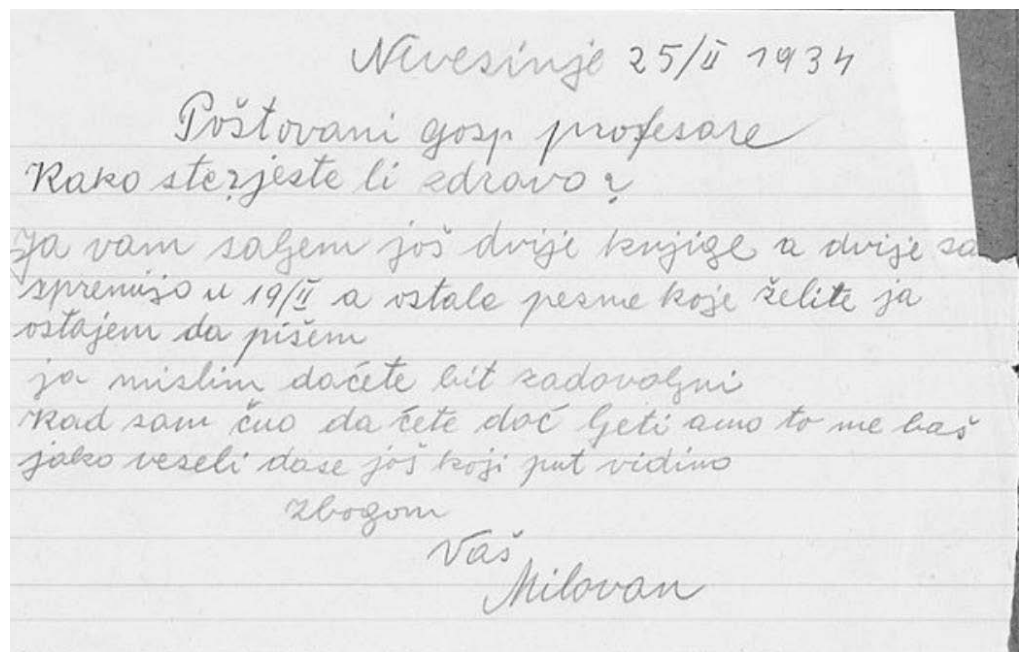

У раније цитираном тексту Гусле на Харварду, Милица Стевановић (2009: 61) структуру нама битног дијела Перијеве колекције описује на сљедећи начин: „Текстови и грамофонске плоче са епским и лирским песмама, причама и разговорима са певачима, које је прикупио Милман Пери током 1933. и током петнаестомесечног боравка 1934/1935. године у Југославији; транскрипције са око 3.500 плоча садржаних у 95 бележница $(14 \mathrm{x} 14 \mathrm{~cm}$, по 120 стр. у свакој); диктиране песме у 800 бележница (14x 14cm, по 200 стр. у свакој)". По овоме није јасно у шта спадају свеске које Војичић редовно шаље Перију, јер и у самој колекцији поред свих пјесама од броја 77, датиране на 13. септембар 1933. године, стоји ознака received, која је јасна потврда да их је добио поштом, за разлику од 13 пјесама, од редног броја 24 до броја 36 , поред којих је уписано да су забиљежене у Невесињу од 23. до 26. августа 1933. године. Ни пјесме записане на терену, нажалост, немају звучни запис, тако да није јасно да ли је и њих Војичић пјевао уз гусле или их је говорио, или можда записане дао Перију. Рукопис и једних и других је веома сличан, а изнад пјесме број 24, коју сам Пери именује Милош Војновић, изнад текста пјесме имамо запис: „Milovan Vojičić (zemljoradnik)

(pismen) star 32 godine

Mjesto Nevesinje (Hercegovina)"'

Уосталом, на већем броју текстова записаних у Невесињу августа 1933. дописано је „Ріsao sam pjevač”, што показује да је за проучаваоца та чињеница била од изузетне важности ${ }^{2}$. Очигледно је већ за свог боравка у Југославији Пери имао на уму могућност да се пјесамама снабдијева и када се врати

\footnotetext{
${ }^{1}$ Сва цитирања Милована Војичића и Милмана Перија наведена су у оригиналном облику, а према: https://mpc.chs.harvard.edu/songs/mp_songs 1-2.html

2 Занимљиво је да уз пјесму бр. 238 (Женидба бега Љубовића) стоји назнака: „Оd pisca M. Vojičića, detalji imadu".
} 
кући, за шта му је Војичић био идеалан сарадник. Милована Војичића можемо представити као типичног сарадника какве је имао и Вук Караџић, какав је био, нпр. Вук Врчевић, односно Петрановићев пјевач Илија Дивјановић. То су били драгоцјени помагачи који су сакупљачу служили као својеврсно врело са којег су они црпли садржај, који су касније могли антологијски распоређивати, што је Вук чинио знатно боље од Петрановића, а у Перијевом случају на располагању имамо цјелокупни корпус који је њему служио за провјеру теорије о усменом стваралаштву које је оваплотио његов ученик и сарадник А. Б. Лорд у књигама Певач прича 1-2.

Војичић је био гуслар, али писмен човјек, школски подворник. У причању његовог сина присутна је хероизација његове биографије ${ }^{3}$, тачније смрти, налична оној која се везује за много знатнијег гуслара Илију Вуковића. Суштински су за проучавање много значајније пјесме о његовом времену, прије свега цијели еп о Великом рату, а све пјесме старијих и средњих времена су, заправо, скоро идентичне варијанте старијих пјесама, што Пери ревносно биљежи, нпр. 118. Часни Крсти записује прибиљешку „Almost word for word Vuk II 17”, заправо 18, или 120. којој он дописује наслов Наход Симеун прецизиравши на врху странице „Copied almost word for word from Vuk 13”, тј. 14, дакле варијанта Тешана Подруговића. Понегдје су те опаске обимније као у случају пјесме, којој такође сам даје наслов Ђакон Стеван $и$ два анђела, са истим појашњењем да недостају четири стиха, 66-69, те да је додат (adding) крај:
„To je bilo kada se činilo
A mi braćo da se veselimo
Veseli nam bože domaćina
I u domu ko mu se desijo
I on mu se vazda veselijo
Sadružinom koja mu je ovđe
Sovom ovđe i kad druga dođe".

Ово упућује на то да је Војичић биљежио пјесме других пјевача, јер је бесмислено да он сам дописује ове стихове, а о чему постоје и Војичићеве забиљешке, нпр. на крају пјесама бр. 220 Свађа између хајдука или бр. 221 Зашто Бајо оде у ускоке стоји забиљешка:
„Od Marka Kešelja pravoslavni
star oko 60 god.
rođak Zovi Dol
Nevesinje.
Živi u bačkoj."

Војичић је Перију у Невесињу записао, ако изузмемо један кратки припјев посвећен његовом омиљеном лику краљу Александру, искључиво пјесме Косовског циклуса и средњих времена, али ниједну о Светом Сави. Четири од пет пјесама о Светом Сави Пери је примио поштом, а поред једне

${ }^{3}$ О овоме видјети више у: Саша Кнежевић, Пјесме Милована Војичића о почетку Великог рата. 
стоји s.d., краћеница за документе који нису датирани. Једна од њих је Како се Свети Сава закалуђерио (133) скоро идентична варијанта истоимене пјесме из збирке Српске народне пјесме - епске пјесме старијег времена Богољуба Петрановића, коју је објавило Српско учено друштво 1867. године. Прео-стале четири: Свети Сава славни (116), Свети Сава и чобанин (134), Свети Сава спасава јањце од Турака (134а) и Молитва српских светаца (234) немају своје варијанте код Петрановића, али имају забиљежене варијанте у Босанској вили или као приповијетке. Фокус нашег интересовања стога је управо на компарацији са раније објављеним текстовима са ужег простора Босне или Херцеговине 4

Занимљиво је да Пери највјероватније није познавао Петрановићеве књиге, јер изнад појединих текстова који су истовјетни Петрановићевим, нпр. Смрт краља Стевана Дечанског (135), која има варијанте у обје његове књиге епских пјесама истоимену (13) у другој и (15) у трећој, али је, с друге стране, поред Вукових збирки био упознат и са Шаулићевом, јер изнад текста бр. 100, који сам Пери именује Светитељ Ђорђије убио аждају, стоји забиљешка „See Šaulić, p. 21”. Отуда и не изненађује да такве прибиљешке нема ни уз пјесму Како се Свети Сава закалуђерио. Ради се о двије скоро идентичне варијанте, сем што Војичићева има стереотипан почетак: „Воžе mili na svemu ti fala”, који је, у различитим модификацијама, стално мјесто не само у преостале четири пјесме него у скоро свим Војичићевим пјесмама. Друга разлика је знатно битнија и односи се на сам крај пјесме, односно њен посљедњи стих:

„И кад виђе Саву и Ђурђинку, Напоредо ђе су преминули, Ту се царе чуду зачудио: „Мили Боже, на свему ти хвала!” Петрановић (1989: 80)
„I kad viđe Savu i Đurđinku Naporedo đe su preminuli Tuse care čudu začudijo Mili Bože na svemu ti fala Kad ja svoju ne ogreših dušu" Vojičić

Војичићева варијанта је захваљујући додатом посљедњем стиху дјелује логичније и потпуније и показује како код Петрановића неријетко изостављање или додавање појединих стихова може знатно покварити пјесму, а на што је давно упозорио и Ватрослав Јагић (в. 1868: 210-230). Веома је занимљиво да је ова пјесма послата 25. 2. 1934, као посљедња свеска о којој имамо податак о пријему, заједно са пјесмама са тематиком везаном за Велики рат: Свјетски рат, Ћесаров ултиматум Србији или Први удар на Србију, а одмах послије ње, на крају те свеске, налазе се и пјесме Свети Сава и чобанин, уз коју се поткрала и пјесма Свети Сава спасава јањие од Турака, коју Пери не региструје као засебан наслов, као и раније помињана Смрт краља Стевана Дечанског. Ово указује на то да је Војичић слао све пјесме до којих

\footnotetext{
${ }^{4}$ У овом раду се нећемо бавити анализом самих пјесама о чему постоји обимна библиографија доступна у раду Наде Милошевић Ђорђевић: Народна предања о Светом Сави и српска средњовековна писана реч.
} 
је могао доћи, што се може објаснити и чињеницом да је за тај труд био и финансијски награђиван, чему је потврда сљедећи запис:

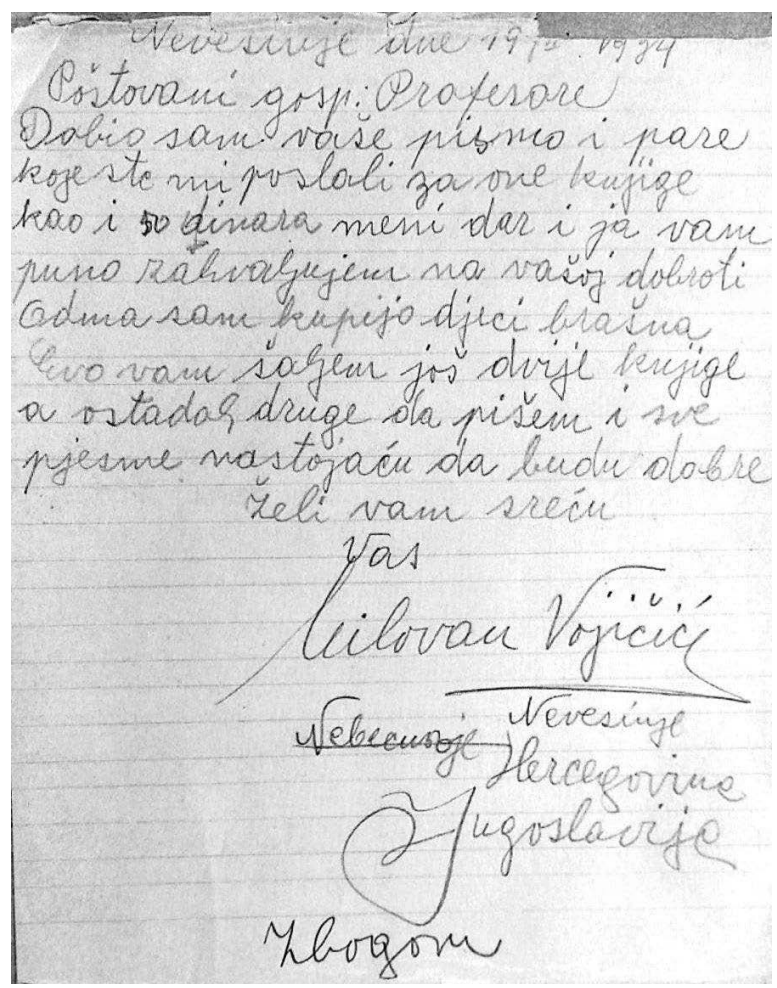

С овим се у везу ваља довести и својеврсни панегирик који је 30. септембра 1933. године Војичић посветио професору Перију, заправо његовом првом пропутовању кроз Југославију, а у част његовог сретног повратка у дичну Америку. На крају ове пјесме стоји да ју је спјевао Милован Војичић, што не проналазимо код других текстова, али сама пјесма указује да је Војичић располагао способношћу спјевавања нових пјесама и завидним фондом епских формула, па је тако Пери „Soko tica siva”, за лађу Сатурнију каже „А brza je kao gorska vila”, а кад на крају свога путовања упутио у Херцеговину „U junačku našu pokrajinu”, Војичић подсјећа да се прије главнине посла „I divno se junak odmorijo”. Гуслар који је способан саставити пјесму од овако неепског садржаја, свакако је вичан и испјевати нове о великим збивањима са почетка вијека. Међутим, пјесме о којима је овдје ријеч ипак су посуђене из старијих извора. Свети Сава и чобанин је, осим неких језичких облика идентична варијанта пјесме из збирке игумана Дионисија Миковића објављене у Босанској вили 1897. године у броју 14-15. Своју варијанту у Босанској вили има и пјесма Свети Сава спасава јањие од Турака, коју Пери није раздвојио од претходне Свети сава и чобанин вјероватно стога што њен дугачки наслов личи на стих. Објављена је у броју 1/XIX, 1904. године под насловом 
Свети Сава и од Војичићеве варијенте се разликује тек у неколико стихова. У пјесми из Виле након седмог стиха „Ал ето ти стара чобанина”, слиједи стих „У руци му сребрена свирала”, док након истовјетног седмог стиха у Војичићевој варијанти осми гласи „С̆obanina Save svetitelja”. Различити су и посљедњи стихови након што Турци схвате превару и камење које је молитва начинила јагањцима побацају на гомилу:

„То не био стари чобанине, Већ то био светитељу Саво." Босанска вила (1897: 221)
„U čudu se Turci nalaziše

Pa ovako jesu govorili

Ovo nam je kazna od alaha" Vojičić

Као и у претходном случају ова варијанта дјелује као надограђена, али уједно и боља верзија чији завршетак има прецизнију и утемељенију поенту. На овим детаљима може се примијенити чувена Вукова (1986: 395) опаска којом издваја Тешана Подруговића од других пјевача јер је: „песме разумевао и осећао, и мислио је шта говори". Несумњиво да је Војичић разумијевао народну пјесму, а и да је и те како мислио о ономе што записује и шаље Перију. Отуда не чуди што је у пјесми Молитва српских светаца у тефтеру српских светитеља „Prvo jeste svetitelju Savo”, како га је дефинисао Веселин Чајкановић (1973: 149) „најнационалнији наш светац”. Да је тај који јесте, потврђује и пјесма Свети Сава славни, која је стихована варијанта легенде из Ћоровићеве књиге Светог Саву срела шьљака. Мотив штаке која у јерусалимској цркви сама долази у руке светитељу по стародревном аманету његовог имењака „ک̌ to je đače bijo u Isusa”, коју је, према причи Свети Сава узео „и донио је из Јерусалима са собом у Србију”, показује нашег светитеља као својеврсну спону српског народа са хришћанском црквом у цјелини, оног „O kojem se pjeva širom svjeta”.

Завршни стихови ове пјесме на најбољи начин потврђују колико је утемељена светосавска идеја у Херцеговини и међу Херцеговцима:

„fala Bogu na daru njegovu

Blago srbma šta su dočekali

Kad imaju svoga svetog savu

Koji moli Boga istinoga

A za sreću naroda srpskoga

Moli Boga za naše spasenje

Bog nam dao zdravlje i veselje"

Управо се у овим стиховима потврђује закључак Ненада Љубинковића (2010: 221): „Народно веровање доделило је светом Сави највеће могуће признање које народ некојем претку може да додели - означио га је властитим прародитељем, родоначалником васколиког народа српског”.

С обзиром на то да исконски народне пјесме о Светом Сави свој праизвор црпе из литургијске књижевности у потпуности се потврђује теза Наде Милошевић Ђорђевић (1998: 325): „Народна епска песма не представља слушаоцима светитеља са циљем да у њима изазове потребу за подражавањем 
његових подвига, већ да га прихвате као значајног претка заштитника који и њима самима даје важно место на лествици цивилизацијских и националних вредности”. Овим се објашњава потреба Милована Војичића да у свој корпус пјесама које шаље Милману Перију уврсти и наслове о Светом Сави и потврђује став да је итекако мислио о томе које и какве стихове ће записати, а на тај начин и разумијевао смисао свога удјела у великом пројекту у којем се прилично изненада нашао. Он није могао понудити оригиналне саставе о Светом Сави, али је инкорпорирао оне које је знао или до којих је у међувремену дошао у цјелокупни корпус којим је репрезентовао своје, али и епско пјевање цијеле Херцеговине тридесетих година двадесетог стољећа.

\section{ЛИТЕРАТУРА}

Босанска вила 1897: Босанска вила, 14-15/XII, Сарајево.

Босанска вила 1904: Босанска вила, 1/XIX, Сарајево.

Јагић 1868: В. Јагић, Српске народне пјесме из Босне и Херцеговине: епске пјесме старијег времена, скупио Богољуб Петрановић, Рad, 2/2, Загреб: JA3У, 204-235.

Караџић 1986: В. С. Караџић, Српске народне пјесме књ. 4, Београд: Просвета. Караџић 1986а: В. С. Караџић, Српске народне пјесме књ. 2, Београд: Просвета. Кнежевић 2015: С. Кнежевић, Пјесме Милована Војичића о почетку Великог рата, Српска књижевност и Први светски рат, Вишеград: Андрићград, $215-228$.

Љубинковић 2010: Н. Љубинковић, Трагања и одговори, Београд: ИКУМ.

Милошевић Ђорђевић 1998: Н. Милошевић Ђорђевић, Епске песме „средњих времена" и српска средњовековна књижевност, у: Свети сава у српској историји и традицији, Београд: САНУ, 321-336.

Милошевић Ђорђевић 2011: Н. Милошевић Ђорђевић, Народна предања о Светом Сави и српска средњовековна писана реч, $y:$ Радост препознавањ $а$, Нови Сад: ИЦ Матице српске, 35-61.

Петрановић 1989: Б. Петрановић, Српске народне пјесме из БиХ II, Сарајево: Свјетлост.

Стевановић 2009: М. Стевановић, Гусле на Харварду, Панчево: Панчевачко читалиште бр. 14, 60-63.

Ћоровић 2011: В. Ћоровић, Педесет легенди о Светом Сави, Чачак: Легенда. Чајкановић 1973: В. Чајкаовић, Мит и религија у Срба, Београд: СКЗ. https://mpc.chs.harvard.edu/songs/mp_songs 1-2.html 
Saša D. Knežević

\section{DAS HERZOGTUM VON SVETI SAVA IN DEN LIEDERN VON MILOVAN VOJIČIĆ}

\section{(Zusammenfassung)}

Sveti Sava taucht sehr oft in den Liedern des wichtigsten Parry-Mitarbeiters Milovan Vojičić auf, aber für diese Arbeit haben wir zehn Lieder ausgewählt, in denen er die Hauptfigur ist. In Vojičićs Oeuvre werden wir versuchen, die Einflüsse früherer poetischer Varianten zu finden, aber auch von Legenden und anderen Prosatypen, die in seiner Heimat weit verbreitet sind. Milovan Vojičić betrachtet Herzegowina als das Herzogtum von Sveti Sava und den Heiligen selbst als Gottes Erkorener, Lehrer und Hüter des Volkes. Daher ist es interessant zu analysieren, wie er die älteren Varianten an seine eigene Vision anpasst. 